\title{
Cryotherapy in the treatment of glandular odontogenic cyst: case report and review
}

\section{Crioterapia no tratamento de cisto odontogênico glandular: relato de caso e revisão}

\author{
Milene Borges Campagnaro* \\ Raquel Medeiros Farias* \\ Roger Correa de Barros Berthold" \\ Márcia Rejane Brücker ${ }^{* * *}$ \\ Fábio Dal Moro Maito ${ }^{* * * *}$ \\ Claiton Heitz ${ }^{* * * *}$
}

\begin{abstract}
Objective: The Glandular Odontogenic Cyst (GOC) is a rare benign odontogenic lesion, of considerable aggression, and often incorrectly diagnosed. We present a patient with a Glandular Odontogenic Cyst in the posterior mandible, its evolution, treatment, and follow-up. Case report: A female patient, 45 years old, was referred to the Oral and Maxillofacial Surgery and Traumatology Division at Cristo Redentor Hospital, Porto Alegre, Brazil, for the assessment of a painful edema on the right hemiface. A unilocular area with well-defined borders in the retromolar region, posterior to the third molar on the right side of the mandible. The histopathological examination suggested GOC. Final considerations: The Glandular Odontogenic Cyst needs a complete clinical assessment associated with image analyses, and especially, with histopathology for the correct diagnosis of the lesion, since the diagnosis may be mistaken in clinical and radiographic examination. There are several treatment options; however, enucleation associated with cryotherapy, in this case, was an effective method for the treatment of Glandular Odontogenic Cyst.
\end{abstract}

Keywords: Cyst. Cryotherapy. Mucoepidermoid Carcinoma.

\section{Introduction}

Glandular Odontogenic Cyst (GOC) was first described by Gardner in 1988 as a distinct clinical pathologic entity, and it was included in the WHO histological typing of odontogenic tumors under GOC or sialo-odontogenic cyst ${ }^{1-5}$.

Glandular Odontogenic Cyst is a rare lesion, of considerable aggressive behavior, originated at the areas of dental support ${ }^{1-5}$. Clinically, the most affected site is the anterior part of the mandible and it mostly occurs in middle-aged patients with a slight male prevalence ${ }^{2,4-8}$. Epidemiological features are scarce due to the rarity of the lesion and a review in 2008 pointed 111 cases published in the literature ${ }^{6}$. In the maxilla, the most affected area is the canine region ${ }^{9}$. The GOC presents an asymptomatic slow-growing edema; nevertheless, it may present an aggressive growth ${ }^{2,3,8}$.

Radiographically, GOC may be unilocular or multilocular with well-defined borders ${ }^{1,2,4,7}$. In addition, it may often show expansion, thinning, erosion, or perforation of cortical plates. However,

Postgraduate student, Department of Oral and Maxillofacial Surgery, Pontifical Catholic University of Rio Grande do Sul, RS, Brazil.

Master student, Department of Oral and Maxillofacial Surgery, Pontifical Catholic University of Rio Grande do Sul, RS, Brazil.

Professsor, Department of Oral Radiology, Pontifical Catholic University of Rio Grande do Sul, RS, Brazil.

Professsor, Department of Oral Pathology, Pontifical Catholic University of Rio Grande do Sul, RS, Brazil

Chairman, professsor, Department of Oral Maxillofacial Surgery, Pontifical Catholic University of Rio Grande do Sul, RS, Brazil. 
it does not show any radiologic pathognomonic aspect differing from ameloblastoma, central giant cell granuloma, odontogenic myxoma, intraosseous mucoepidermoid carcinoma, and odontogenic keratocyst tumor ${ }^{5,8,9}$.

A cyst wall lining of non-keratinized squamous epithelium, with papillary projections, nodular thickenings, and mucous-filled clefts, characterizes the histological aspect of GOC. The superficial cells tend to be cuboidal and irregular with papillary surfaces. It is indispensable to analyze different regions of the histological examination; this allows identifying the lesion since there are many similar characteristics $^{1,2,10-13}$.

The treatment of GOC included curettage, enucleation, and en bloc resection ${ }^{3,4,8,13,14}$. This lesion presents high recurrence rates when conservative treatment is applied. Cryotherapy is the local or general use of low temperatures in medical therapy to treat benign and malignant lesions ${ }^{8,15}$. The use of extreme temperatures kills cells by crystalizing the cytosol. Usually employed in oral and maxillofacial surgery to treat odontogenic keratocyst tumor after enucleation, cryotherapy decreased the recurrence rate of this lesion ${ }^{15}$. The use of cryotherapy appears to be an ally in the treatment of COG, as well as odontogenic keratocyst tumor, becoming a less invasive option than en bloc resection, with good results.

The aim is to report a case of GOC treated with enucleation and cryotherapy, which features proservation of 6 years with no recurrence.

\section{Case report}

A 45-year-old female patient was referred to the oral and Maxillofacial Surgery and Traumatology Division at Cristo Redentor Hospital, Porto Alegre, Brazil, for the assessment of a painful edema at the back right side of the mandible, third molar region. She had already consulted with an otorhinolaryngologist who treated her, unsuccessfully, with antibiotics and had recently extracted the right lower third molar. Even after surgery, there was no remission of symptoms and edema.

The radiological evaluation showed hypodense areas in the posterior portion of the right mandible: the most anterior area, consistent with the healing process after tooth extraction; and posterior area of the lesion, hypodense, unilocular with well-defined borders. After reviewing the images, acquired by iCT Philips scanner, a probable diagnosis of odontogenic keratocyst tumor was suggested, even though there was rupture of the lingual cortical plate, which is not a common radiological feature of this tumor (Figure 1).

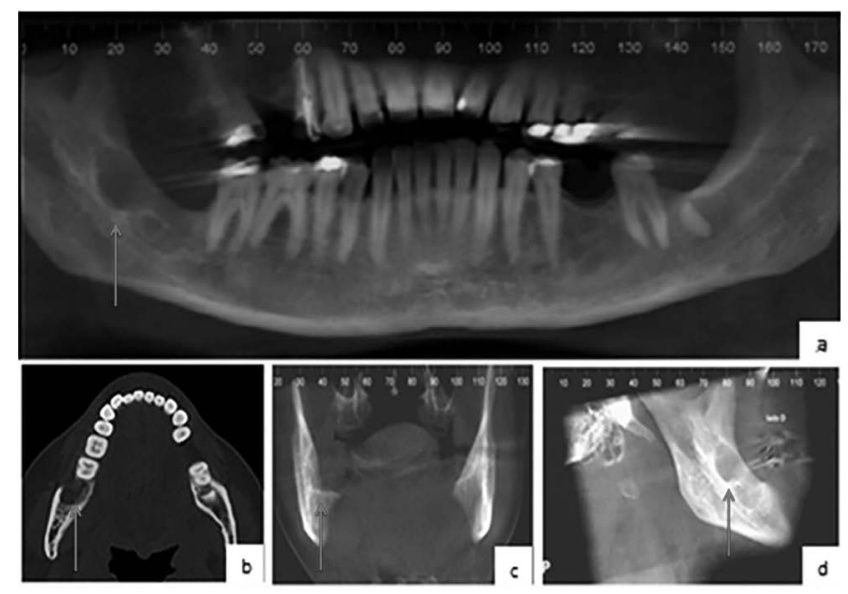

Figure 1 - Preoperative

(a) Panoramic tomography slice showing a hypodense unilocular lesion with well-defined borders on the right side of the mandible.

(b,c,d) CT: reconstructed axial, coronal, and sagittal planes revealing a hypodense area, an involvement of the soft tissue with the lesion, and rupture of the lingual cortical plate is observed.

Source: all figures are prepared by the authors.

The patient underwent general anesthesia for surgical excision through an intraoral approach. As prior incisional biopsy had not been performed, cryotherapy was used considering the clinical and radiographic similarity of this lesion to odontogenic keratocyst tumor, which is an already established benefit of this therapy. Cryotherapy was applied to the surgical defect, using the proposed protocol by Santana et al. After enucleation, the adjacent tissues were protected with dry gauze pads, and liquid nitrogen cryotherapy was applied to the surgical site by a cryosurgery device (CRY-AC-3 No. B700; Brymill, Basingstoke, United Kingdom) with a spray tip. The cryosurgery tip and a N. 12 tracheal aspiration tube were used to apply the liquid nitrogen directly to the bone cavity. Two cryotherapy applications were performed for one minute each, with an interval of five minutes between applications.

The histopathological examination revealed cyst wall lined by stratified squamous epithelium of varying thickness along with epithelial whorls in a few areas, and the superficial layer of the epithelium showed eosinophilic cuboidal and columnar ciliated cells with papillary projections, mucous cells, nodular thickenings, and mucous-filled clefts suggesting GOC (Figure 2). 

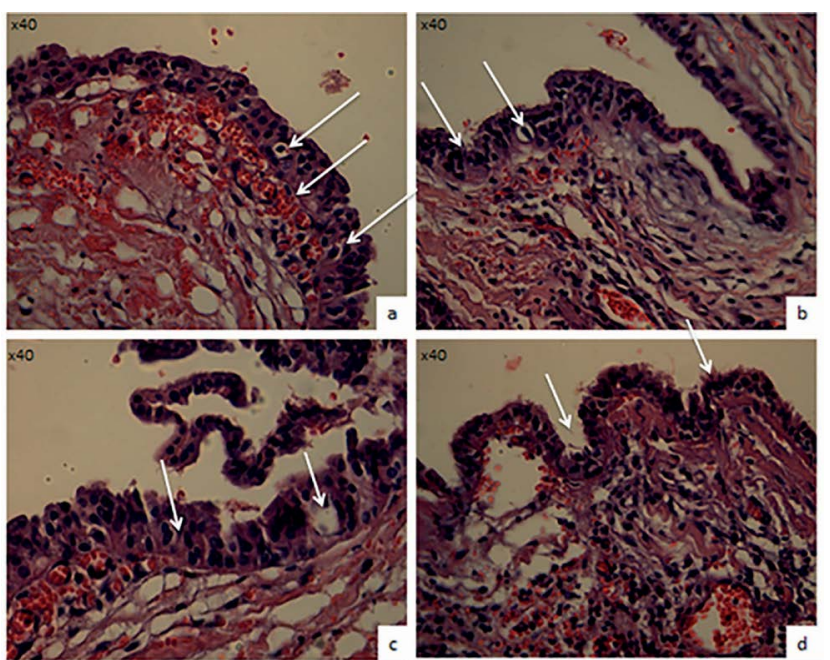

Figure 2 - Histopathology

(a,b,c,d). Cyst wall lined by stratified squamous epithelium of varying thickness along with epithelial whorls in a few areas. The superficial layer of the epithelium showed eosinophilic cuboidal, borderline flat, columnar ciliated cells, mucous cells, intraepithelial glandular or duct-like structures and papillary surface (HE staining)

The patient is being monitored and, up to the present moment, six years after surgery, there were no recurrences (Figure 3).

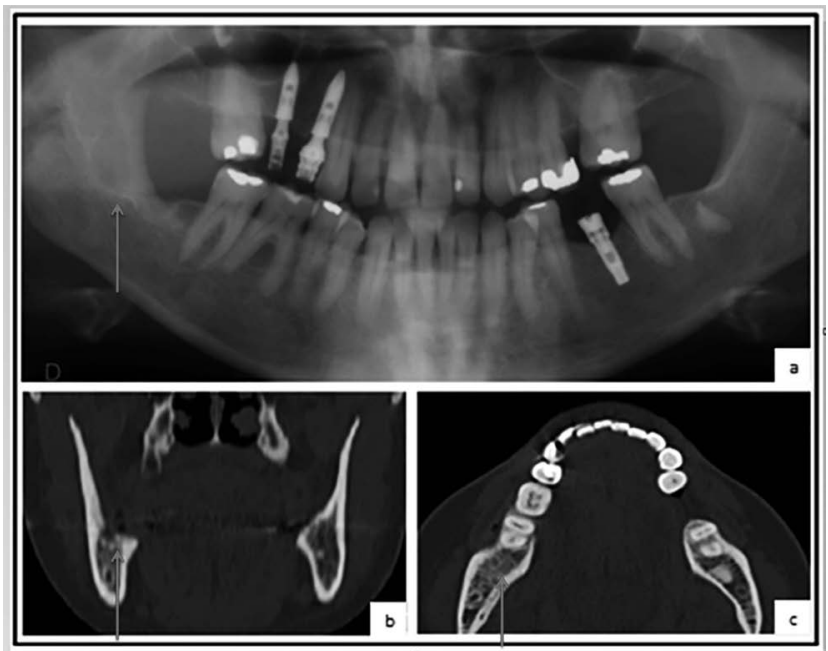

Figure 3 - Postoperative

(a,b,c) Panoramic radiograph, coronal, and axial CT showing absence of lesion.

\section{Discussion}

The GOC is a rare lesion characterized by slow-growing painless edema, having a slight male prevalence, and occurring predominantly in the anterior area of the mandible. Although the clinical findings are varied and often not pathognomonic, it may occasionally be followed by pain, as in the case presented $^{1-8}$.

Radiographically, the GOC is located intraosseously and may appear as a multilocular or unilocular hypodense lesion with well-defined borders. Sometimes it may present peripheral osteoesclerotic border, scalloping with resorption, tooth displa- cement, and many different diagnosis are included such as ameloblastoma, odontogenic keratocyst tumor, and intraosseous mucoepidermoid carcino$\mathrm{ma}^{1,2,4,5,7,9}$.

Histologically, the cyst wall is coated by stratified squamous epithelium with variable thickness, cuboid epithelial surface, and ciliated and mucous cells along with glandular structures and papillary surface $^{1,2,10-13}$. It may be mistaken by intraosseous mucoepidermoid carcinoma (MEC); however, this occurs besides mucosal cells, skin cells, cellular atypia, and mitotic activity, even depending on the grade of the tumor. Also common is the presence of intermediate cells that have scant cytoplasm and solid islands of squamous and intermediate cells, containing pleomorphisms and mitotic activity ${ }^{9,11}$.

A review of several parts of the area in the histopathological examination is essential to correctly identify the lesion, since there are many similar characteristics to other conditions. In the case described, cuts of the entire piece were analyzed, therefore excluding the possibility of treating an odontogenic keratocyst tumor or an intraosseous mucoepidermoid carcinoma, since the histological features were consistent determinants of $\mathrm{COG}^{1,2,10-13}$.

The treatment of choice is still controversial and ranges from curettage, enucleation, and en bloc resection. The behavior of the tumor must be taken in account. The recurrence rate is directly related to the size and the locularity of the lesion, and conservative treatments are associated with high recurrence rates. The patient must be monitored for a long period of time $\mathrm{e}^{3,4,8,9,13,14,16}$. Due to the clinical and radiological features of a benign cystic lesion and the provisional diagnosis of odontogenic keratocyst tumor, an excisional biopsy and cryotherapy were performed ${ }^{15}$. To our knowledge, this is the first report regarding adjuvant cryotherapy treatment of GOC.

Cryotherapy kills cells by means of direct damage to intracellular and extracellular surfaces, forming ice crystals that affect the osmotic and electrolytic balance. The purpose of the enucleation technique combined with liquid nitrogen cryotherapy is to remove the visible pathological tissue, also aiming at necrosis by freezing possible resting cells that may lead to recurrence. Liquid nitrogen has cell-necrotizing properties and preserves inorganic bone structures in contrast to carnoy solution, which destroys osteogenic and osteoconductive properties $^{15}$. In a six-year follow-up, no recurrence was observed in the patient.

\section{Final considerations}

In conclusion, this case report of GOC extends the scientific knowledge of this rare cyst to a new adjuvant associated with enucleation - cryotherapy, which suggests to improve treatment effectiveness, and be more conservative than en bloc resection. 
However, little is known about the simultaneous use of cryotherapy in this type of lesion. Further studies to assess the long-term benefits and the reduction of relapses will be needed.

\section{Resumo}

Objetivo: o cisto odontogênico glandular (COG) é uma lesão odontogênica benigna rara, de considerável agressão, muitas vezes diagnosticada incorretamente. Apresentamos um paciente com um cisto odontogênico glandular em região posterior de mandíbula, sua evolução, tratamento e acompanhamento. Relato de caso: paciente do gênero feminino, 45 anos, que foi encaminhada à equipe de cirurgia e traumatologia bucomaxilofacial do Hospital Cristo Redentor, Porto Alegre, Brasil, para a avaliação de um edema doloroso em hemiface direita. Uma área unilocular com bordas bem definidas na região retromolar, posterior ao terceiro molar, no lado direito da mandíbula. A análise histopatológica sugeriu COG. Considerações finais: o cisto odontogênico glandular precisa de uma avaliação clínica completa, associada a exames de imagem e, especialmente, à histopatologia para o correto diagnóstico da lesão, uma vez que o diagnóstico pode ser confundido no exame clínico e radiográfico. Existem várias opções de tratamento, no entanto, a enucleação associada à crioterapia, nesse caso, foi um método eficaz para o tratamento do cisto odontogênico glandular.

Palavras-chave: Cisto. Crioterapia. Carcinoma mucoepidermoide.

\section{References}

1. Manzini M, Deon C, Dalla Corte L, Bertotto JC, Abreu LB. Glandular odontogenic cyst: an uncommon entity. Braz J Otorhinolaryngol 2009; 75(2):320.

2. Guruprasad Y, Chauhan DS. Glandular odontogenic cyst of maxilla. J Clin Imaging Sci 2011; 1:54.

3. Jankowski MD. Glandular odontogenic cyst: systematic review. Dentomaxillofac Radiol 2010; 39(3):127-39.

4. Rao JB, Kumar KA J, Kumar BP. Glandular odontogenic cyst involving the posterior part of maxillary sinus, a rare entity. J Maxillofac Oral Surg 2010; 9(1):72-5.

5. Krishnamurthy A, Sherlin HJ, Ramalingam K, Natesan A, Premkumar P, Ramani P et al. Glandular odontogenic cyst: report of two cases and review of literature. Head Neck Pathol 2009; 3(2):153-8.

6. Kaplan I, Anavi Y, Hirshberg A. Glandular odontogenic cyst: challenge in diagnosis and treatment. Oral Dis 2008; 14(7):575-81.

7. Stoelinga PJ. The management of aggressive cyst of the jaw. J Maxillofac Oral Surg 2012; 11(1):2-12.

8. Turali S, Yazicioğlu D, Euqül KC, Telcioqlu NT, Karasu HA. Recurrent glandular odontogenic cyst treatment. Kulak Burun Bogaz Ihtis Derg 2012; 22(3):176-80.

9. Moghadam AS, Moghadam AF. Intraosseous mucoepidermoid carcinoma: report of two cases. J Dent Shiraz Univ Med Sci 2014; 15(2):86-90.

10. Fowler CB, Brannon RB, Kessler HP, Castle JT, Kahn MA. Glandular odontogenic cyst: analysis of 46 cases with special emphasis on microscopic criteria for diagnosis. Head Neck Pathol 2011; 5(4): 364-75.

11. Waldron AC. Odontogenic cysts and tumor. In: Neville BW, Damm DD, Allen CM, Bouquot JE. Oral and Maxillofacial Pathology. Philadelphi: Sawders; 1995. p. 493-540.

12. Takeda Y. Glandular odontogenic cyst mimicking a lateral periodontal cyst: a case report. Int J Oral Maxillofac Surg 1994; 23(2):96-7.

13. Manor R, Anavi Y, Kaplan I, Calderon S. Radiological features of glandular odontogenic cyst. Dentomaxillofac Radiol $2003 ; 32(2): 73-9$

14. Cano J, Benito DM, Montáns J. Glandular odontogenic cyst: two high-risk cases treated with conservative approaches. J Craniomaxillofac Surg 2012; 40(5):131-6.

15. Tonietto L, Borges HO, Martins CA, Silva DN, Sant'Ana Filho M. Enucleation and liquid nitrogen cryotherapy in the treatment of keratocystic odontogenic tumors: a case series. J Oral Maxillofac Surg 2011; 69(6):112-7.

16. Morais HHA, Vasconcellos RJH, Santos TS, Queiroz LMG, Silveira ÉJD. Glandular odontogenic cyst: case report and review of diagnostic criteria. J Craniomaxillofac Surg 2012; 40(2):46-50.

\section{Correspondence address:}

Claiton Heitz

Ipiranga Avenue, 6.681

90619-900 Porto Alegre, RS

Phone: (55) (51) 3320-3538/ 9993-1336

Email: claitonheitz1@gmail.com

Recebido: 06/03/14. Aceito: 04/01/16. 